\title{
SELF-MANAGEMENT INTERVENTION OF ELDERLY HYPERTENSION: A LITERATURE REVIEW
}

\author{
Endah Sri Wijayanti ${ }^{1}$, Moses Glorino Rumambo Pandin ${ }^{2}$ \\ ${ }^{1}$ Student at Faculty of Nursing, Universitas Airlangga, Surabaya, Indonesia \\ ${ }^{2}$ Associate Professor at English Department, Faculty of Humanities, Universitas Airlangga, \\ Surabaya, Indonesia \\ Email: endah.sri.w-2020@ fkp.unair.ac.id, moses.glorino@ fib.unair.ac.id
}

\begin{abstract}
Background: Indonesia is an archipelago with various cultured, will bee affects all aspects of people's lives, including beliefs related to health behavior and health care. One problem that needs serious attention is the elderly group because the elderly are a vulnerable group who have a high risk of experiencing health problems, such as anemia with hypertension, so they need good care management. The research objective was to determine selfmanagement intervention for hypertensive elderly. Methods: This research is a literature review with five databases (Scopus, CINAHL, ScienceDirect, PubMed, Proquest), the study design used is an experimental, descriptive, cross-sectional, and review systematic, in March 2021. Guidelines for using JBI to measure quality and listing check out Prisma in this review guide. A feasibility study based on title, abstract, full text, and research methodology. The data analysis used narrative analysis based on the research findings. Results: Twelve articles met the predefined review inclusion criteria. The study found eight interventions for self-management in elderly hypertension, namely: 1) Knowledge of hypertension, 2) Regulation of physical activity, 3) Limitation of alcohol and cigarette consumption, 4) Sleep rest and stress management, 5) Diet and body weight management, 6) Blood pressure control, 7) Family and social support, 8) Adherence to therapy regimens. Conclusion: The conclusion of the study results obtained eight elderly self-management interventions, this done properly will affect compliance in optimizing the health of the elderly.
\end{abstract}

Keywords: Hypertension; Elderly; Intervention; Self-management

\section{BACKGROUND}

Indonesia is an archipelago with various cultures, thus influencing all aspects of people's lives, including beliefs related to health behavior and health care. One problem that needs serious attention is the elderly group (elderly) because the elderly are a vulnerable group who have a high risk of experiencing health problems(1). The Elderly is the last stage in the life cycle marked by changes and decreases physically, psychologically, socially, and spiritually are related components(2,3).Indonesia has a high birth rate and challenge of increasing of elderly, due to increased life expectancy. The elderly are a group that is vulnerable to a decline in health, which has an increasing health 
cost, decreasing income, lack of social support, social support, and family support $(4,5)$. One in four elderly experiences health problems in a month, to decreased endurance and organ function $(4,6)$.

The Elderly is a degenerative process and a decrease in body function that they experience health problems. The elderly are included in the vulnerable group. One of the health problems of non-communicable diseases experienced by the elderly is hypertension. Hypertension is one of the health problems of non-communicable diseases caused by the increased risk of cardiovascular disease $(7,8)$. The prevalence of hypertension in the world reaches $29.2 \%$ in men and $24.8 \%$ in women. Hypertension has caused the death of around 8 million people every year, 1.5 million deaths occur in Southeast Asia, one-third of the population suffers from hypertension $(9,10)$. Hypertension of the elderly caused the degenerative process. The aging process results in endothelial dysfunction and increases arterial stiffness to increasing blood pressure $(11,12)$.

Primary hypertension occurs due to risk factors such as lifestyle, high salt consumption, excessive alcohol consumption, smoking, being overweight, decreased physical activity, and increased stress $(13,14)$. The risk factors for hypertension in the elderly are increasing age, family history of cardiovascular disease,obesity-related hypercholesterolemia, unhealthy lifestyles such as smoking, alcohol consumption, a diet high in salt and fat, and decreased physical activity (15).

The elderly with hypertension require good health care management and selfmanagement of the elderly with hypertension. Hypertension service management involves multidisciplinary and collaboration between health workers(16).The minimum health services provided to patients with hypertension are routine blood pressure checks and BMI monitoring; health education; provide adherence guidelines for drug avoidance; guidelines for the care and timely utilization of health services; monitoring of patient status and health reports $(11,17)$. Self-management of sufferers of chronic disease has been proven to be cost-effective but has complex factors at play. The influence factors of self-management for the elderly with hypertension are demographics, knowledge of the disease, social support, self-efficacy, and self-management $(11,18)$.

Self-management consists of medication adherence, health monitoring, diet management, exercise management, work management, and emotional management. The results suggest that old age increases the risk of cardiovascular disease. Educational factors and group support also influence positive patient self-management(19,20).Influenced by factors patient adherence is of age, level of education, and residence with family. Patient 
adherence is to be better at a younger age, higher education, and family support(21).

The management of elderly care with hypertension requires adherence to health care for the elderly by involving the family. Prevent complications, as cerebrovascular disease, heart disease, kidney disease, peripheral vascular disease, kidney disease, diabetes mellitus(22,23).Prevention of hypertension can provide self-management counseling, to manage yourself in everyday life to adapt to the disease and maintain quality of life(22). Hypertension self-management to manage hypertension related to treatment, prevention of disease progression and its complications, with responsibility for their health care(24).Many studies discuss health problems in the elderly, but those related to selfmanagement in the elderly are still rare. Therefore, it is necessary to conduct a literature review to identify self-management interventions of the elderly with hypertension. The purpose of this study was to explore the self-management intervention of the elderly with hypertension.

\section{METHOD}

The research design is a literature review using the PRISMA checklist to determine the selection of studies that have been found and adjusted to the research objectives. The electronic database uses five databases, namely Scopus, CINAHL, ScienceDirect, PubMed, Proquest. Search for articles was carried out in March 2021 using Boolean Operators (AND, OR) and keywords adjusted to the Medical Subject Heading (MeSH), namely: hypertension AND elderly AND "self-management" with full-text inclusion criteria in English for the period 2019 to 2021. Based on the results of a literature search on five databases, 259 articles. The search results have obtained checked for duplication, found 51 similar articles to excluded, and the remaining 208 articles. The researcher then conducted a screening based on the title $(n=208)$, abstract $(n=52)$, and full text $(n=12)$ adjusted to the theme of the literature review. The assessment was a thorough selection based on the eligibility of the inclusion and exclusion criteria 12 articles have obtained that match the predetermined criteria and used in the literature review.

\section{RESULT AND DISCUSSION}

\section{Knowledge about Disease}

Health education about hypertension aims to make the elderly and families understand the process of hypertension, signs, and hypertension symptoms $(25,26)$. The early stages require an assessment of disease, self-efficacy, self-management behavior. The 
aim to determine the level of knowledge and understanding of clients about hypertension. The client's knowledge of the disease process experienced will determine the nurse's actions in providing self-management support, procedures, care coordination, and supervision related to client health(7).Health education based on the Health Belief Model can increase the confidence of the elderly with hypertension about health and improve the self-care behavior of the elderly (27).

\section{Physical Activity Settings}

An unhealthy lifestyle leads to increased cholesterol and excess salt. An unhealthy lifestyle accompanied by low physical activity is one of the causes of hypertension. Physical activity in the elderly can adjust their abilities, routines, and activities that are not strenuous. Heavy and tiring activities can also cause stress for the elderly(28). Physical activity recommended for the elderly is morning walks, healthy heart exercises, and all forms of daily activities for the elderly. Achieving a regular physical activity in the elderly requires family support(29). The suggests that regular physical activity can reduce the risk of hypertension. Recommended physical activity for the elderly as regular and targeted exercise increase blood flow (21).

\section{Limitation consumption of alcohol and cigarettes}

The elderly should always get support from family to quit smoking, get rid of smoking, follow recommendations for alcohol use. Long-term consumption of alcohol and cigarettes is a toxic element in the hair of people with hypertension who are smokers and drinkers of alcohol(17). Smoking can increase the build-up of fibrinogen to block blood flow cause vasoconstriction of blood vessels. The nicotine in cigarettes can stimulate the adrenal glands to increase adrenal secretion results in myocardial irritability, increased heart rate, and vasoconstriction, thereby increasing blood pressure(14). Excessive alcohol consumption can stimulate adrenaline. Alcohol stimulated epinephrine or adrenaline, in arterial vasoconstriction, and build-up of water and sodium. The release of epinephrine or adrenaline can increase blood pressure(30).

\section{Stress Management and Sleep Rest}

The elderly can carry out stress management strategies, relaxation techniques, and maintain adequate sleep to meet the resting needs of the elderly(11,31). The elderly are at risk for depression because of the health problems they experience. The cases of elderly 
hypertension in urban areas are higher than in rural areas because of the dense environmental conditions, congestion, increased crime, increased stress, and illness to stress. Hypertension is trigger by stress requires stress management to reduce stress and reduce blood pressure in the elderly with hypertension(32).

Stress causes an increase in the production of renin-angiotensin-aldosterone (RAA), causes narrowing of the arteries increases blood volume, which triggers an increase in blood pressure. Good stress management can reduce the product of renin-angiotensinaldosterone (RAA). Stress management through quality sleep rest, relaxation techniques such as deep breathing, warm compresses, counseling, psychotherapy, and emotional support in the elderly(16). Psychological factors such as anxiety and stress are risk factors for hypertension in the elderly. The elderly need to sleep rest to restore the physiological and psychological functions of the body. Sleep disorders in the elderly, especially the NREM phase, will cause cardiovascular system disorders such as increased blood pressure, heart rate, and peripheral vascular resistance(17). his need for sleep in the elderly is related to the psychological and physiological conditions of the elderly's body.

\section{Diet and Weight Management}

The elderly possible should have an ideal weight, follow the recommended diet, limit salt intake, limit high-calorie drinks and snacks, reduce food portions, and limit caffeine consumption(28). he elderly decrease in metabolic processes and lack of physical activity causes weight results in obesity due to the accumulation of cholesterol and fat (33).The sodium content in salt binds water. The high water content that enters intravascularly causes an increase in blood volume. If the blood volume increases, work the heart will increase and cause blood pressure to increase well. The more angiotensin the kidneys produce, the more sodium is stored in the body, and water is retained in body tissues. Total cardiac output is influenced by blood volume, whereas blood volume is highly dependent on body homeostasis(21).

Hypertension diet management in the elderly is influenced by the elderly's applying the type of food that the elderly can consume in a certain amount. A healthy diet is applied diet low in salt and low in fat, reducing processed foods and fruits that contain alcohol. Educating about a healthy diet can use a food model, is hoped that the elderly will better understand the hypertensive diet, goals, foods that are allowed, not allowed, limited, and eat portions of the elderly as needed $(17,19)$. 


\section{Blood Pressure Control}

Blood pressure monitoring in the elderly with hypertension includes monitoring blood pressure, performing proper procedures to measure blood pressure, checking the calibration of a blood pressure meter if you have one at home, maintaining blood pressure targets, using a diary to monitor blood pressure from time to time, and contacting health services(25). Blood pressure monitoring aims to monitor blood pressure conditions so that it can prevent uncontrolled hypertension. Uncontrolled hypertension increases the risk of complications. Controlling blood pressure can be included as part of the daily activity schedule for the elderly with hypertension(34).

Blood pressure monitoring at home, but the elderly should still carry out consultations and health checks at health services. Health workers can provide specific information about the category of blood pressure test results and things that must consider and actions that must be the results of the examination show hypertension, such as contacting the nearest health service (10). The patient understands normal blood pressure targets, frequency of self-examination, records of the examination, and consults a health worker regarding the results. The Elderly can monitor blood pressure at home, but the elderly need counseling with health education officers (20). Monitoring blood pressure at home will make it easier for the elderly to increase patient adherence to treatment (16).

\section{Family and Social Support}

Social support is needed by the elderly through support groups, using information and community resources, seeking financial resources, and social support (35). Family support in carrying out family health care duties can affect the care of elderly with hypertension at home. The regularity of the elderly in their health care requires family support the main support system for the elderly $(3,17,22)$.

Elderly self-care management to assess self-control, self-efficacy, problem-solving abilities, psychosocial treatment, support, motivation, and ability to make decisions related to healthy behavior. Social support to find out the help and support received from people(22). Support for the elderly with hypertension is the support of health workers who help patients with diet, exercise, and medication adherence. Patients who have good social support will have a higher coping ability than patients who live alone. The Elderly will have good coping if health workers discuss providing education about coping strategies by involving family participation (9).

Social support increases adherence in the treatment of hypertension. Social support is from family, friends, and people around the patient. Patients with hypertension 
experience non-compliance in their health management, especially in the care and management of a healthy lifestyle. Adherence is influenced by motivation and social support from the family(28,34).Social support useful increasing motivation sharing information, helping with crises, and caring for health. Functional social support affects patient compliance to control blood pressure. Adherence to hypertension treatment can prevent complications, improve quality of life, save on treatment costs (36).

\section{Adherence to Therapeutic Regimens}

The elderly can get medication as prescribed and monitor the side effects of treatment(28,37). At level 1 hypertension (systolic blood pressure 140-159 $\mathrm{mmHg}$ and or diastolic blood pressure 90-99 $\mathrm{mmHg}$ ), blood pressure checks and monitoring and lifestyle changes are carried out(2).Patient adherence is a major determinant of the success of therapy. Adherence and good understanding in carrying out therapy can affect blood pressure and prevent complications(18). Some of the reasons that patients do not use antihypertensive drugs are due to the nature of the disease which naturally causes no symptoms, long-term therapy, side effects of drugs, complex therapeutic regimens, lack of understanding of the management and risk of hypertension, and the relatively high cost of treatment $(26,38)$.

\section{CONCLUSION}

Nursing interventions that can improve self-management of hypertensive elderly are: 1) Knowledge of disease, 2) Regulation of physical activity, 3) Limitation of alcohol and cigarette consumption, 4) Sleep rest and stress management, 5) Diet and weight management, 6 ) Blood pressure control, 7) Family and social support, 8) Adherence to therapy regimens.

\section{REFERENCES}

1. Wang N, Xu J, Ma M, Shan L, Jiao M, Xia Q, et al. Targeting vulnerable groups of health poverty alleviation in rural China - what is the role of the New Rural Cooperative Medical Scheme for the middle age and elderly population? Int J Equity Health. 2020 Dec;19(1):161.

2. Rusmauli R, Sianipar CM. Pengaruh Edukasi Manajemen Diri Terhadap Dan Tekanan Darah Pasien Hipertensi Di Ruang Rawat Inap Rumah Santa Elisabeth Medan. Elisabeth Heal J [Internet]. 2020 Jun 18;5(1):104-12. Available from: http://ejournal.stikeselisabethmedan.ac.id:85/index.php/EHJ/article/view/289

3. Zhang X, Zheng Y, Qiu C, Zhao Y, Zang X. Well-being mediates the effects of social support and family function on self-management in elderly patients with hypertension. 
Psychol Health Med [Internet]. 2020 May 27;25(5):559-71. Available from: https://www.tandfonline.com/doi/full/10.1080/13548506.2019.1687919

4. Kemenkes RI. Hasil Utama Riskesdas 2018 [Internet]. Badan Penelitian dan Pengembangan Kesehatan. 2018 [cited 2021 Mar 15]. Available from: https://www.litbang.kemkes.go.id/hasil-utama-riskesdas-2018/

5. Badan Pusat Statistik. Statistik Penduduk Lanjut Usia 2020 [Internet]. Badan Pusat Statistik RI. 2020 [cited 2021 Mar 15]. Available from: https://www.bps.go.id/publication/2020/12/21/0fc023221965624a644c1111/statistikpenduduk-lanjut-usia-2020.html

6. Kemenkes RI. Situasi dan analisis Lanjut Usia [Internet]. Pusat Data dan Informasi Kementerian Kesehatan RI. 2019 [cited 2021 Mar 15]. Available from: https://pusdatin.kemkes.go.id/resources/download/pusdatin/profil-kesehatanindonesia/PROFIL_KESEHATAN_2018_1.pdf

7. Aprilatutini T, Sihotang R, Utama TA, Yustisia N. Self Care Management Evaluation In Hypertension Patients. J Vokasi Keperawatan [Internet]. 2021 Jan 1;3(2):184-202. Available from: https://ejournal.unib.ac.id/index.php/JurnalVokasiKeperawatan/article/view/13935

8. Song $\mathrm{C}$, Li $\mathrm{X}$, Ning $\mathrm{X}$, Song S. Nursing case management for people with hypertension. Medicine (Baltimore) [Internet]. 2020 Dec 24;99(52):e23850. Available from: https://journals.lww.com/10.1097/MD.0000000000023850

9. Tapela NM, Clifton L, Tshisimogo G, Gaborone M, Madidimalo T, Letsatsi V, et al. Prevalence and Determinants of Hypertension Awareness, Treatment, and Control in Botswana: A Nationally Representative Population-Based Survey. Int J Hypertens [Internet]. 2020 May 31;2020:1-12. Available from: https://www.hindawi.com/journals/ijhy/2020/8082341/

10. Turana Y, Tengkawan J, Soenarta AA. Asian management of hypertension: Current status, home blood pressure, and specific concerns in Indonesia. J Clin Hypertens [Internet]. $2020 \quad$ Mar 4;22(3):483-5. Available from: https://onlinelibrary.wiley.com/doi/abs/10.1111/jch.13681

11. Chaboksavar F, Azar FEF, Solhi M, Azadi NA. Combination of self-management theory with PRECEDE-PROCEED model to promote life quality in patients with hypertension. J Public Health (Bangkok) [Internet]. 2020 Apr 3; Available from: http://link.springer.com/10.1007/s10389-020-01246-7

12. Shareinia H, Sadeghmoghadam L, Mokhtarzadeh MR, Zahrayi SM, Jafari N, Noori R. Relationship Between Polypharmacy and Medication Adherence in the Hypertensive Elderly Patients. Dis Diagnosis [Internet]. 2020 Dec 30;9(4):153-7. Available from: https://ddj.hums.ac.ir/Article/ddj-249

13. AlHadlaq R, Swarelzahab M, AlSaad S, AlHadlaq A, Almasari S, Alsuwayt S, et al. Factors affecting self-management of hypertensive patients attending family medicine clinics in Riyadh, Saudi Arabia. J Fam Med Prim Care [Internet]. 2019;8(12):4003. Available from: http://www.jfmpc.com/text.asp?2019/8/12/4003/272490

14. M. Yatim H, Wong YY, Neoh CF, Lim SH, Hassali MA, Hong YH. Factors influencing patients' hypertension self-management and sustainable self-care practices: a qualitative study. Public Health [Internet]. 2019 Aug;173:5-8. Available from: https://linkinghub.elsevier.com/retrieve/pii/S0033350619301441

15. Akseer N, Mehta S, Wigle J, Chera R, Brickman ZJ, Al-Gashm S, et al. Noncommunicable diseases among adolescents: current status, determinants, interventions and policies. BMC Public Health [Internet]. 2020 Dec 14;20(1):1908. Available from: https://bmcpublichealth.biomedcentral.com/articles/10.1186/s12889-020-09988-5

16. Zhang Y, Fang Y, Xu Y, Xiong P, Zhang J, Yang J, et al. Adherence with blood 
pressure monitoring wearable device among the elderly with hypertension: The case of rural China. Brain Behav [Internet]. 2020 Jun 9;10(6). Available from: https://onlinelibrary.wiley.com/doi/10.1002/brb3.1599

17. Ding W, Li T, Su Q, Yuan M, Lin A. Integrating factors associated with hypertensive patients; self-management using structural equation model: a cross-sectional study in Guangdong, China. Patient Prefer Adherence [Internet]. 2019 Oct;Volume 12:216978. Available from: https://www.dovepress.com/integrating-factors-associated-withhypertensive-patients-self-managem-peer-reviewed-article-PPA

18. Delavar F, Pashaeypoor S, Negarandeh R. The effects of self-management education tailored to health literacy on medication adherence and blood pressure control among elderly people with primary hypertension: A randomized controlled trial. Patient Educ Couns [Internet]. 2020 Feb;103(2):336-42. Available from: https://linkinghub.elsevier.com/retrieve/pii/S0738399119303684

19. Hearn J, Ssinabulya I, Schwartz JI, Akiteng AR, Ross HJ, Cafazzo JA. Selfmanagement of non-communicable diseases in low- and middle-income countries: A scoping review. Joshi R, editor. PLoS One [Internet]. 2019 Jul 3;14(7):e0219141. Available from: https://dx.plos.org/10.1371/journal.pone.0219141

20. Shahaj O, Denneny D, Schwappach A, Pearce G, Epiphaniou E, Parke HL, et al. Supporting self-management for people with hypertension. J Hypertens [Internet]. 2019 Feb;37(2):264-79. Available from: https://journals.lww.com/00004872201902000-00004

21. Becker J, Emmert-Fees KMF, Greiner GG, Rathmann W, Thorand B, Peters A, et al. Associations between self-management behavior and sociodemographic and diseaserelated characteristics in elderly people with type 2 diabetes - New results from the population-based KORA studies in Germany. Prim Care Diabetes [Internet]. 2020 Oct;14(5):508-14. Available

from: https://linkinghub.elsevier.com/retrieve/pii/S1751991819304115

22. Zhang Y, Liu S, Sheng X, Lou J, Fu H, Sun X. Evaluation of a community-based hypertension self-management model with general practitioners. Int J Health Plann Manage [Internet]. 2019 Jul 31;34(3):960-74. Available from: https://onlinelibrary.wiley.com/doi/abs/10.1002/hpm.2867

23. Diana R, Nurdin NM, Anwar F, Riyadi H, Khomsan A. Risk Factors of Hypertension among Adult in Rural Indonesia. J Gizi dan Pangan [Internet]. 2019 Nov 15;13(3):111-6. Available from: http://journal.ipb.ac.id/index.php/jgizipangan/article/view/19038/15808

24. Parati G, Lombardi C, Pengo M, Bilo G, Ochoa JE. Current challenges for hypertension management: From better hypertension diagnosis to improved patients' adherence and blood pressure control. Int J Cardiol [Internet]. 2021 May;331:262-9. Available from: https://linkinghub.elsevier.com/retrieve/pii/S0167527321001522

25. Zhang Y, Yang N, Si G, Zhang Y, Dong Z, Huang Y, et al. What matters the adherence with BP 24-hr self-monitoring wearable device among hypertensive patients? A population-based survey. Transl Behav Med [Internet]. 2020 Oct

8;10(4):1053-63.
https://academic.oup.com/tbm/article/10/4/1053/5511699

26. Roulet C, Rozsnyai Z, Jungo KT, A. van der Ploeg M, Floriani C, Kurpas D, et al. Managing hypertension in frail oldest-old-The role of guideline use by general practitioners from 29 countries. Shimosawa T, editor. PLoS One [Internet]. $2020 \mathrm{Jul}$ 10;15(7):e0236064. Available from: https://dx.plos.org/10.1371/journal.pone.0236064

27. Arindari DR, Suswitha D. Health Belief Model Factors to Medication Adherence among Hypertensive Patients in Punti Kayu Public Health Center Palembang, 
Indonesia. J Keperawatan. 2020 Jan;11(1):26.

28. Adinkrah E, Bazargan M, Wisseh C, Assari S. Adherence to Hypertension Medications and Lifestyle Recommendations among Underserved African American Middle-Aged and Older Adults. Int J Environ Res Public Health [Internet]. 2020 Sep 8;17(18):6538. Available from: https://www.mdpi.com/1660-4601/17/18/6538

29. Anandh S, Varadharajulu G, M. Alate M, Patil DM. Effect of Mindful Outdoor Walking on Attention Among Independent Rural Elderly. Int J Curr Res Rev [Internet]. 2021;13(01):75-9. Available from: https://ijcrr.com/uploads/3273_pdf.pdf

30. Mills KT, Stefanescu A, He J. The global epidemiology of hypertension. Nat Rev Nephrol [Internet]. 2020 Apr 5;16(4):223-37. Available from: http://www.nature.com/articles/s41581-019-0244-2

31. Benetos A, Petrovic M, Strandberg T. Hypertension Management in Older and Frail Older Patients. Circ Res [Internet]. 2019 Mar 29;124(7):1045-60. Available from: https://www.ahajournals.org/doi/10.1161/CIRCRESAHA.118.313236

32. Hou Y, Wu Q, Zhang D, Jin X, Wu W, Wang X. The differences in self-perceptions of aging, health-related quality of life and their association between urban and rural Chinese older hypertensive patients. Health Qual Life Outcomes [Internet]. 2020 May 26;18(1):154. Available from: http://www.ncbi.nlm.nih.gov/pubmed/32456638

33. Labata BG, Ahmed MB, Mekonen GF, Daba FB. Prevalence and predictors of self care practices among hypertensive patients at Jimma University Specialized Hospital, Southwest Ethiopia: cross-sectional study. BMC Res Notes [Internet]. 2019 Dec 14;12(1):86. Available

from: https://bmcresnotes.biomedcentral.com/articles/10.1186/s13104-019-4125-3

34. Foroumandi E, Kheirouri S, Alizadeh M. The potency of education programs for management of blood pressure through increasing self-efficacy of hypertensive patients: A systematic review and meta-analysis. Patient Educ Couns [Internet]. 2020 Mar;103(3):451-61. Available from: https://linkinghub.elsevier.com/retrieve/pii/S0738399119304240

35. Qu Z, Parry M, Liu F, Wen X, Li J, Zhang Y, et al. Self-management and blood pressure control in China: a community-based multicentre cross-sectional study. BMJ Open [Internet]. 2019 Mar 20;9(3):e025819. Available from: https://bmjopen.bmj.com/lookup/doi/10.1136/bmjopen-2018-025819

36. Manangkot MV, Saputra IK, Suindrayasa IM. Family's knowledge, attitude, and behavior in supporting self-care management of hypertensive patients of community health care centers in Denpasar. Enfermería Clínica [Internet]. 2020 Dec;30:78-81. Available from: https://linkinghub.elsevier.com/retrieve/pii/S1130862120304666

37. Demirtürk E, Hacıhasanoğlu Aş1lar R. The effect of depression on adherence to antihypertensive medications in elderly individuals with hypertension. J Vasc Nurs [Internet]. 2018 Sep;36(3):129-39. Available from: https://linkinghub.elsevier.com/retrieve/pii/S1062030318300311

38. Unda Villafuerte F, Llobera Cànaves J, Lorente Montalvo P, Moreno Sancho ML, Oliver Oliver B, Bassante Flores P, et al. Effectiveness of a multifactorial intervention, consisting of self-management of antihypertensive medication, self-measurement of blood pressure, hypocaloric and low sodium diet, and physical exercise, in patients with uncontrolled hypertension taking 2 o. Medicine (Baltimore) [Internet]. 2020 Apr;99(17):e19769. Available from: https://journals.lww.com/10.1097/MD.0000000000019769 